\title{
Yield Response of Upland Rice as Influenced by Enhanced-Efficiency Nitrogen Fertilizers in the Brazilian Cerrado
}

\author{
Vinícius Almeida Oliveira ${ }^{1}$, Eliana Paula Fernandes Brasil ${ }^{2}$, Welldy Gonçalves Teixeira ${ }^{2}$, \\ Felipe Corrêa Veloso dos Santos ${ }^{3} \&$ Atila Reis da Silva ${ }^{4}$ \\ ${ }^{1}$ Faculdade Central Cristalinense, Cristalina, GO, Brazil \\ ${ }^{2}$ Federal University of Goiás, Goiânia, GO, Brazil \\ ${ }^{3}$ School of Engineering, Pontifical Catholic University of Rio de Janeiro, Goiânia, GO, Brazil \\ ${ }^{4}$ Instituto Federal Goiano, Goiânia, GO, Brazil \\ Correspondence: Welldy Gonçalves Teixeira, Campus Samambaia, Agronomy School, Federal University of \\ Goiás, Goiânia, Goiás, Brazil. Tel: 55-62-991-711-481. E-mail: welldygteixeira@gmail.com
}

Received: June 22, 2020

Accepted: August 5, 2020

Online Published: October 15, 2020

doi:10.5539/jas.v12n11p98

URL: https://doi.org/10.5539/jas.v12n11p98

\begin{abstract}
Nitrogen $(\mathrm{N})$ fertilizers have their use efficiency adversely affected by the rate and source of $\mathrm{N}$. A two-year field experiment was conducted to examine the yield response of upland rice by using NBPT (urease inhibitor), PCU (polymer-coated urea) and uncoated urea under different $\mathrm{N}$ application rates. It was hypothesized that either NPBT or PCU may result in increased yield components of upland rice when compared to conventional urea. The experiment was set up in a randomized block design in a $3 \times 4+1$ factorial scheme, with four replicates. Treatments comprised three sources (conventional uncoated urea, NBPT-treated urea, and polymer-coated urea) and four rates $\left(30,60,90\right.$ and $\left.120 \mathrm{~kg} \mathrm{ha}^{-1}\right)$ of $\mathrm{N}$, in addition to a control treatment (no fertilizer application). Nitrogen fertilizers were applied in two split doses: $50 \%$ at the seedling stage, and $50 \%$ at the tillering stage ( 80 days after planting). The results revealed that the use of enhanced-efficiency $\mathrm{N}$ sources increased the productivity and plant height of upland rice crop when compared to conventional urea. As compared to when it is untreated or polymner-coated, treating urea with NBPT resulted in increased 100-grain weight.
\end{abstract}

Keywords: grain yield, fertilizer efficiency, Oryza sativa L.

\section{Introduction}

Rice (Oryza sativa L.) is one of the major food crops for more than 3.5 billion (> 50\%) people in the world (CGIAR, 2016). It is a staple food in the diet of many developing countries, particularly in Asia, Latin America and Africa (Fageria et al., 2011). Based on FAO's forecasts for cereal production, 516.8 million tonnes of rice was harvested in 2019, led by China and India (FAO, 2019). Brazil s among the ten largest rice producers worldwide, accounting for 7.2 million tonnes, down $11.7 \%$ from the previous year's output because of the reduction in the planted area (FAO, 2019). The traditional methods for cultivating rice are known as upland rice and irrigated lowland rice, which are distinguished by the soil's water availability. Due to lower yield as compared with flooded rice, upland rice contributes less than $40 \%$ of total rice production in Brazil (Barbosa Filho \& Yamada, 2002).

To produce high grain yields, modern rice cultivars require adequate amount of essential nutrients. Nitrrogen $(\mathrm{N})$ fertilizers are extensively used by farmers to enhance rice crop production, as $\mathrm{N}$ is usually the most limiting nutrient except in soils containing high content of organic matter (V. B. Singh \& V. K. Singh, 2017). Rice crops use $1 \mathrm{~kg}$ of $\mathrm{N}$ to produce $68 \mathrm{~kg}$ of grain (Witt et al., 1999). Deficiency of $\mathrm{N}$ in plants rapidly slows shoot growth and lead to severe nutritional disorders.

Fertilizer N-use efficiency by the crops is typically low. In general, plants assimilate less than $50 \%$ of the N applied (Tilman et al., 2002; Dobermann \& Cassman, 2004), turning the $\mathrm{N}$ losses into a potential source of environment pollution. The supply of to crop plants comes from various sources, including native soil $\mathrm{N}$ crop residues, animal manure, and inorganic or mineral fertilizers (Ladha et al., 2005). In the case of rice, $\mathrm{N}$ fertilizers have their use efficiency adversely affected by the rate and source of $\mathrm{N}$. Inadequate rate of $\mathrm{N}$ fertilizer 
application, as well as poor $\mathrm{N}$ management strategies lead to substantial losses of $\mathrm{N}$ due to inherently low $\mathrm{N}$ uptake capacity and absence of extensive root system in rice (Sinclair \& Rufty, 2012).

The major contributors to $\mathrm{N}$ losses in rice systems are nitrification-denitrification, ammonia $\left(\mathrm{NH}_{3}\right)$ volatilization (Buresh et al., 2008), and to a less extent, leaching (Linquist et al., 2013). In non-flooded soils, $\mathrm{NH}_{3}$ volatilization is of primary concern, particularly when $\mathrm{N}$ is applied as urea in alkaline soils. Urea is quickly hydrolysed to $\mathrm{NH}_{3}$ and $\mathrm{CO}_{2}$ after it is added to the soil, resulting in an increase of the soil $\mathrm{pH}$ and $\mathrm{NH}_{4}^{+}$around the fertilizer granule (Francis et al., 2008). Under alkaline conditions, the equilibrium of $\mathrm{NH}_{3}-\mathrm{NH}_{4}$ is shifted more to $\mathrm{NH}_{3}$, increasing volatilization losses that lead to lower fertilizer $\mathrm{N}$ use efficiencies (Ladha et al., 2005).

Several approaches have been adopted for reducing $\mathrm{N}$ losses and enhancing the $\mathrm{N}$ use efficiency by the crops. The use of formulated forms of fertilizer containing urease and nitrification inhibitors to reduce $\mathrm{NH}_{3}$ volatilization from urea hydrolysis has emerged as an effective strategy.

Urease inhibitor NBPT [N-(n-butyl) thiophosphorictriamide] has been reported to significantly inhibit the activity of the urease enzyme, which reduces $\mathrm{NH}_{3}$ volatilization losses due to urea application to rice (Buresh et al. 1988; Norman et al., 2009). Polymer-coated urea (PCU) is another important alternative to uncoated urea for improving $\mathrm{N}$-use efficiency since it synchronizes $\mathrm{N}$ release and crop $\mathrm{N}$ uptake with minimum side effects (Patil et al. 2010).

Many researchers have recorded significant increase in grain yield of flood rice due to combined application of either NBPT + urea or PCU + urea over application of urea alone (Dillon et al., 2012; Norman et al., 2009; Pang \& Peng 2010; Rogers et al., 2015). However, only a few studies discuss their utility for lowland rice systems. Hence, a two-year field experiment was conducted to examine the yield response of upland rice by using NBPT, PCU and uncoated urea under different $\mathrm{N}$ application rates. It was hypothesized that either NPBT or PCU may result in increased yield components of upland rice when compared to conventional urea.

\section{Materials and Methods}

\subsection{Experiment Site}

The field experiment was carried out in two growing seasons (2013/14 and 2014/15) in an area $\left(16^{\circ} 35^{\prime} 50^{\prime \prime}\right.$ S; $49^{\circ} 16^{\prime} 40^{\prime \prime} \mathrm{W} ; 735 \mathrm{~m}$ a.s.l.) located in the Agronomy College at the Federal University of Goiás, State of Goiás, Brazil. The local climate is classified as Aw (seasonal tropical savanna), with a humid season from October to April and a dry one from May to September according to the Köppen classification. The average annual precipitation is $1500 \mathrm{~mm}$, and the mean annual temperature is around $22.5^{\circ} \mathrm{C}$. The soil was classified as typic dystrophic Red Latosol (LVd) in the Brazilian Soil Classification System (Santos et al., 2013), which corresponded to an Oxisol in the US Soil Taxonomy System (Soil Survey Staff, 2003). Prior to characterization, soil samples were air dried and sieved through a 2-mm mesh and then analysed following methodologies as proposed by Embrapa $(1997,2009)$. Some selected chemical properties and particle size distribution of the top-layer soil $(0-20 \mathrm{~cm})$ at the beginning of the experiment in 2013 are given in Table 1.

Table 1. Selected chemical properties and particle size distribution of the soil at the experimental site

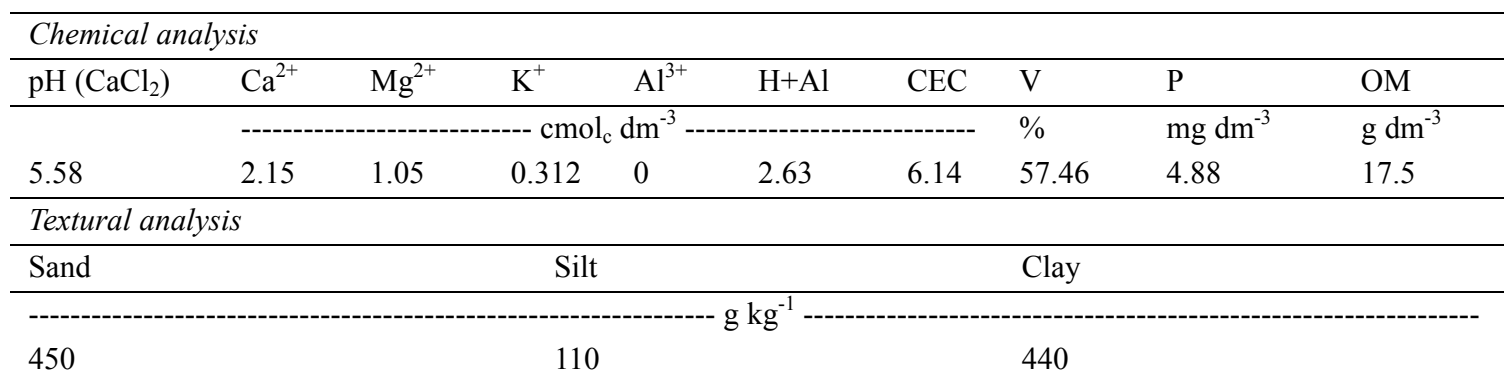

Note. $\mathrm{Ca}^{2+}, \mathrm{Mg}^{2+}$, and $\mathrm{Al}^{3+}$ were extracted by $1 \mathrm{~mol} \mathrm{~L}^{-1} \mathrm{KCl} ; \mathrm{P}$ and $\mathrm{K}$ were extracted by $0.05 \mathrm{~mol} \mathrm{~L}^{-1} \mathrm{HCl}+0125$ $\mathrm{mol} \mathrm{L}^{-1} \mathrm{H}_{2} \mathrm{SO}_{4}$ (Mehlich-1 extractor); $\mathrm{H}+\mathrm{Al}$ was extracted by $0.5 \mathrm{~mol} \mathrm{~L}^{-1}$ calcium acetate buffered at $\mathrm{pH} 7$; $\mathrm{CEC}$ (cation exchange capacity): $\sum(\mathrm{K}, \mathrm{Ca}, \mathrm{Mg}) / \sum(\mathrm{K}, \mathrm{Ca}, \mathrm{Mg}, \mathrm{H}+\mathrm{Al}) \times 100 ; \mathrm{V}$ (base saturation): $\sum(\mathrm{K}, \mathrm{Ca}, \mathrm{Mg}) / \mathrm{CEC}$ ] $\times 100$; OM (organic matter) was estimated from the organic carbon $(\mathrm{C})$ extracted by the Walkley-Black method. Textual Analysis conducted using the pipette method. 


\subsection{Experimental Design and Treatments}

The experiment was set up in a randomized block design in a $3 \times 4+1$ factorial scheme, with four replicates. Treatments comprised three sources (conventional uncoated urea, NBPT-treated urea, and polymer-coated urea) and four rates $\left(30,60,90\right.$ and $\left.120 \mathrm{~kg} \mathrm{ha}^{-1}\right)$ of $\mathrm{N}$, in addition to a control treatment (no fertilizer application).

\subsection{Field Experiment}

Field was ploughed at $20 \mathrm{~cm}$ depth prior to seeding. Plots consisted of four 5 meters long rows, spaced $0.5 \mathrm{~m}$ apart, using the rice cultivar BRS Esmeralda, which has a moderate resistance to major diseases and a certain tolerance to water stress (Castro et al., 2014). Additionally, BRS Esmeralda is a relatively recent upland rice cultivar developed by the breeding program coordinated by the Brazilian Corporation for Agricultural Research (EMBRAPA). The higher performance of BRS Esmeralda compared to other current cultivars is due to its high grain quality, good drought tolerance, high disease resistance and lodging resistance (Colombari Filho et al., 2013). Further, this cultivar has a great stability and adaptability to a large range of soils, climates, and crop management on the Cerrado region, wich may lead to a satisfactory yield performance in this study.

The useful area of the plot was composed of the two central rows, considering the lateral rows as borders. The soil was prepared in both years by one plowing and one disk harrow leveling. The seeds of rice were sown manually $20 \mathrm{~cm}$ spaced apart in rows, with two or three seeds per hole. Nitrogen fertilizers were applied in two split doses: $50 \%$ at the seedling stage, and $50 \%$ at the tillering stage ( $\sim 80$ days after sowing). All treatments received $400 \mathrm{~kg} \mathrm{ha}^{-1}$ of the formula $00-20-20$ as a basal fertilizer to supply phosphorus and potassium. Weed management consisted of hand weeding plots two times during the growing season. Rice was harvested in every growing season at the end of maturing stage (between 103 and $108 \mathrm{~d}$ after sowing).

\subsection{Measurements}

At harvest, plots were evaluated for the following yield components: plant height, which consisted in the length of the central culm; number of panicles per linear meter; 100-grain weight, which was randomly evaluated by collecting and weighing 100 fertile spikelets, and corrected to $13 \%$ of water content; and the grain yield, which was determined by weighing the harvested grain of each useful plot, corrected to $13 \%$ of the water content and converted to $\mathrm{kg} \mathrm{ha}^{-1}$ as productivity.

\subsection{Statistical Analysis}

Data from both growing seasons were subjected to an analysis of variance. The statistical model used included sources of variation due to replication, growing season, $\mathrm{N}$ source, $\mathrm{N}$ rate and the interaction of growing season $\times$ $\mathrm{N}$ source, growing season $\times \mathrm{N}$ rate, $\mathrm{N}$ source $\times \mathrm{N}$ rate, and growing season $\times \mathrm{N}$ source $\times \mathrm{N}$ rate. For qualitative factors (growing seasons and $\mathrm{N}$ sources), the means were compared by the Tukey test at the $P<0.05$ level when the $\mathrm{F}$ test proved significant, whereas the quantitative factors $(\mathrm{N}$ rates) were submitted to regression analysis. Sigmaplot 10.0 was used to create figures.

\section{Results and Discussion}

Statisitical analysis show the differences in plant height, number of panicles, 100-grain weight, and productivity of rice between or among growing seasons, $\mathrm{N}$ sources and $\mathrm{N}$ rates (Table 2). However, interaction effects of the factors growing season, $\mathrm{N}$ sources and $\mathrm{N}$ rates on the yield responses of upland rice were not significant $(P>$ $0.05)$.

Plant height significantly increased with the addition of $\mathrm{N}$ rates of all the three $\mathrm{N}$ sources (Figure 1). The increase was in a quadratic form when $\mathrm{N}$ rates were increased in the range of 0 to $120 \mathrm{~kg} \mathrm{ha}^{-1}$, and varied from 83 to $101 \mathrm{~cm}$ in $2013 / 14$, and from 85 to $102 \mathrm{~cm}$ in $2014 / 15$ on average across the $\mathrm{N}$ rates regardless of the $\mathrm{N}$ sources (Figure 1). When the effect of $\mathrm{N}$ rates was analysed for each $\mathrm{N}$ source, maximum plant height was obtained with the application of $\mathrm{N}$ at a rate of $119 \mathrm{~kg} \mathrm{ha}^{-1}$ by UU, $102 \mathrm{~kg} \mathrm{ha}^{-1}$ by PCU, and $81.25 \mathrm{~kg} \mathrm{ha}^{-1}$ by NBPT in the 2013/14 season. In the 2014/15 season, however, higher rates of UU (180 kg ha $\left.{ }^{-1}\right)$, PCU (125 kg $\left.\mathrm{ha}^{-1}\right)$ and NBPT $\left(95 \mathrm{~kg} \mathrm{ha}^{-1}\right)$ were needed to achieve the maximum height of rice plants. Improvements in plant height with the addition of $\mathrm{N}$ in rice grown on Brazilian soils has also been reported by other authors (Fageria \& Santos, 2018; Fageria et al., 2011). In our study, the increase in plant height in response to the application of N rates is probably due to enhanced availability of $\mathrm{N}$ with all the $\mathrm{N}$ sources, thereby indicating that high $\mathrm{N}$ inputs inhibited the effect of fertilizers. In a two-growing season experiment with rice plants, Lyu et al. (2015) found the same result on the response of plant height to $\mathrm{N}$ sources in both seasons, and they also reported changes in the plant height by application of $\mathrm{N}$ up to the highest level of $\mathrm{N}$. 
Table 2. Analysis of variance for the yield response of upland rice (cultivar BRS Esmeralda) to the use of untreated and uncoated urea (UU), polymer-coated urea (PCU) and urease inhibitor NBPT-treated urea (NBPT) under different $\mathrm{N}$ application rates in two growing seasons

\begin{tabular}{|c|c|c|c|c|c|}
\hline \multirow{2}{*}{ Source } & \multirow{2}{*}{$\mathrm{DF}$} & \multicolumn{4}{|c|}{ MS } \\
\hline & & $\mathrm{PH}$ & NP & 100-GW & PROD \\
\hline Growing season (GS) & 1 & $174.97^{*}$ & $537.63^{\circ}$ & $0.501^{*}$ & $1739418.80^{\circ}$ \\
\hline $\mathrm{N}$ source $(\mathrm{S})$ & 2 & $136.52^{* *}$ & $603.33^{\Delta}$ & $0.301^{*}$ & $2518689.11^{*}$ \\
\hline $\mathrm{N}$ rate $(\mathrm{R})$ & 4 & $1086.48^{* *}$ & $4790.57^{* *}$ & $0.745^{* *}$ & $20169969.71^{* *}$ \\
\hline $\mathrm{GS} \times \mathrm{S}$ & 2 & $16.51^{\mathrm{ns}}$ & $100.83^{\mathrm{ns}}$ & $0.020^{\mathrm{ns}}$ & $187314.74^{\mathrm{ns}}$ \\
\hline $\mathrm{GS} \times \mathrm{R}$ & 4 & $4.43^{\mathrm{ns}}$ & $112.28^{\mathrm{ns}}$ & $0.051^{\mathrm{ns}}$ & $938235.84^{\mathrm{ns}}$ \\
\hline $\mathrm{S} \times \mathrm{R}$ & 8 & $40.97^{\mathrm{ns}}$ & $69.96^{\mathrm{ns}}$ & $0.166^{*}$ & $1293977.53^{\mathrm{ns}}$ \\
\hline $\mathrm{GS} \times \mathrm{S} \times \mathrm{R}$ & 8 & $9.31^{\mathrm{ns}}$ & $138.23^{\mathrm{ns}}$ & $0.031^{\mathrm{ns}}$ & $186977.50^{\mathrm{ns}}$ \\
\hline Residual & 87 & 27.66 & 138.72 & 0.064 & 453841.42 \\
\hline C.V.\% & & 5.56 & 14.06 & 9.90 & 15.61 \\
\hline General mean & & 94.66 & 83.78 & 2.56 & 4316.23 \\
\hline
\end{tabular}

Note. DF, degrees of freedom; MS, mean square; PH, plant height; NP, number of panicles; 100-GW, 100-grain weight; PROD, productivity. ${ }^{\Delta},{ }^{\circ},{ }^{*},{ }^{* *},{ }^{\text {ns }}$ significant at the $20,10,5$ and $1 \%$ probability levels and non-significant, respectively.

Notably, a similar pattern for plant hight for all the tested fertilizers was observed in both 2013/14 and 2014/15 growing seasons, except for the conventional untreated urea (UU) in 2014/15, which led to plant height up to $4 \%$ lower than those achieved upon application of the enhanced-efficiency $\mathrm{N}$ fertilizers (Table 3). This finding confirmed the higher positive effect of polymer-coated urea (PCU) and urease inhibitor NBPT-treated urea (NBPT) on rice growing compared with UU.
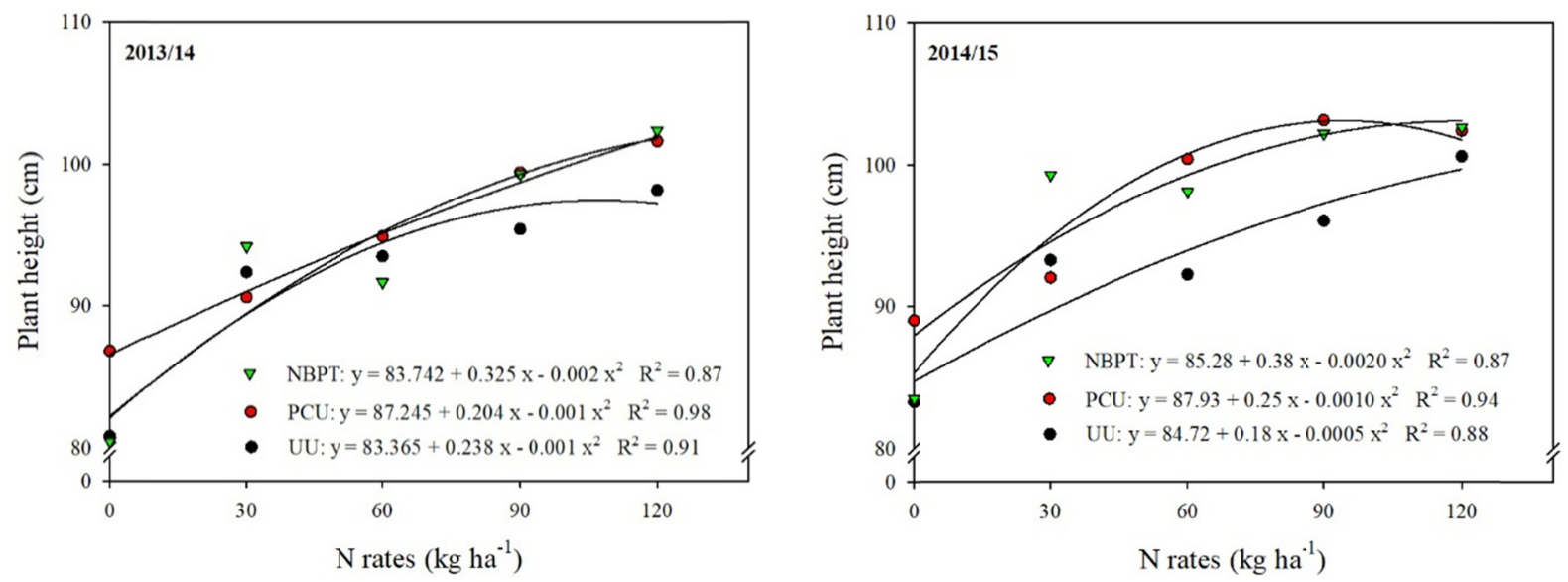

Figure 1. Plant height of upland rice (cultivar BRS Esmeralda) as a function of $\mathrm{N}$ rates by untreated and uncoated urea (UU), polymer-coated urea (PCU) and urease inhibitor NBPT-treated urea (NBPT) during 2013/14 and 2014/15 growing seasons

Similar to plant height, the 100-grain weights $(100-\mathrm{GW})$ increased in a quadratic form with the addition of $\mathrm{N}$ rates by all $\mathrm{N}$ sources in both seasons, varyin from 2.25 to $2.55 \mathrm{~g}$ in 2013/14, and from 2.27 to $2.60 \mathrm{~g}$ in $2014 / 15$ on average across the $\mathrm{N}$ rates regardless of the $\mathrm{N}$ sources (Figure 2). When the effect of $\mathrm{N}$ rates was analysed for each $\mathrm{N}$ source, maximum 100-GW was obtained in 2013/14 with the application of $\mathrm{N}$ at a rate of $50 \mathrm{~kg} \mathrm{ha}^{-1}$ by UU, $69 \mathrm{~kg} \mathrm{ha}^{-1}$ by PCU, and $110 \mathrm{~kg} \mathrm{ha}^{-1}$ by NBPT, whereas $26 \mathrm{~kg} \mathrm{ha}^{-1}$ by UU, $100 \mathrm{~kg} \mathrm{ha}^{-1}$ by PCU, and $100 \mathrm{~kg}$ $\mathrm{ha}^{-1}$ by NBPT were needed to achieve the maximum $100-\mathrm{GW}$ in $2014 / 15$. Noteworthy, increasing the $\mathrm{N}$ application rates from 0 to $120 \mathrm{~kg} \mathrm{ha}^{-1}$ did not cause expressive improvements in the rice grain weight despite its significant effect (Table 2). This finding may be attributed to the influence of some limiting factor affecting the rice grain yield, as discussed in more details bellow. 
Table 3. Plant height (PH), 100-grain weight (100-GW) and productivity (PROD) of upland rice (cultivar BRS Esmeralda) affected by $\mathrm{N}$ fertilizers at the maturing stage during 2013/14 and 2014/15 growing seasons

\begin{tabular}{lccc}
\hline Treatments & PH & $100-\mathrm{GW}$ & PROD \\
\hline & $\mathrm{cm}$ & $\mathrm{g}$ & $\mathrm{kg} \mathrm{ha}^{-1}$ \\
UU & & $2013 / 14$ & $3858.50 \mathrm{~b}$ \\
PCU & $92.06 \mathrm{a}$ & $2.55 \mathrm{a}$ & $4318.25 \mathrm{ab}$ \\
NBPT & $94.69 \mathrm{a}$ & $2.41 \mathrm{a}$ & $4410.75 \mathrm{a}$ \\
& $93.62 \mathrm{a}$ & $2.54 \mathrm{a}$ & $4229.00 \mathrm{a}$ \\
UU & & $2014 / 15$ & $4416.00 \mathrm{a}$ \\
PCU & $93.07 \mathrm{~b}$ & $2.73 \mathrm{a}$ & $4664.88 \mathrm{a}$ \\
NBPT & $97.40 \mathrm{a}$ & $2.52 \mathrm{~b}$ & $2.64 \mathrm{ab}$ \\
\hline
\end{tabular}

Note. UU, uncoated urea; PCU, polymer-coated urea; NBPT, urease inhibitor N-(n-butyl) thiophosphorictriamide. Means followed by the same lowercase letters in the columns are not significantly different by the Tukey test at $5 \%$ probability level.

All the three N sources produced the same grain weight in 2013/14, but they significantly affected the 100-GW in 2014/15. As such, the highest grain weights in the second rice growing season were recorded in plants fertilized with UU, followed by NBPT and PCU (Table 3). Opposite results reported that slow- or controlled-release urea compared with common urea significantly improved grain yield of maize plants owing to an increase in 1000-grain weight (Yang et al., 2017). In our study, the reason why the highest 100-GW season was found in rice plants treated with UU is unknown, since we expected that the greater plant height recorded in the the 2014/15 season with the PCU and NBPT treatmments would favor the grain weight of rice plants treated with such $\mathrm{N}$ sources. However, rice growth and development are mainly affected by water management (Ye te al., 2013; Xu et al., 2018) and according to Heinemann et al. (2011), the water deficit is one of the most important abiotic stress limiting upland rice yield in the Cerrado region of Brazil, where the experiments were carried out. In addition, slow-release fertilizers are highly affected by meteorological conditions in different growing seasons (Guo et al., 2016), and their effects may be weakened by adverse climate changes (Yang et al., 2018).
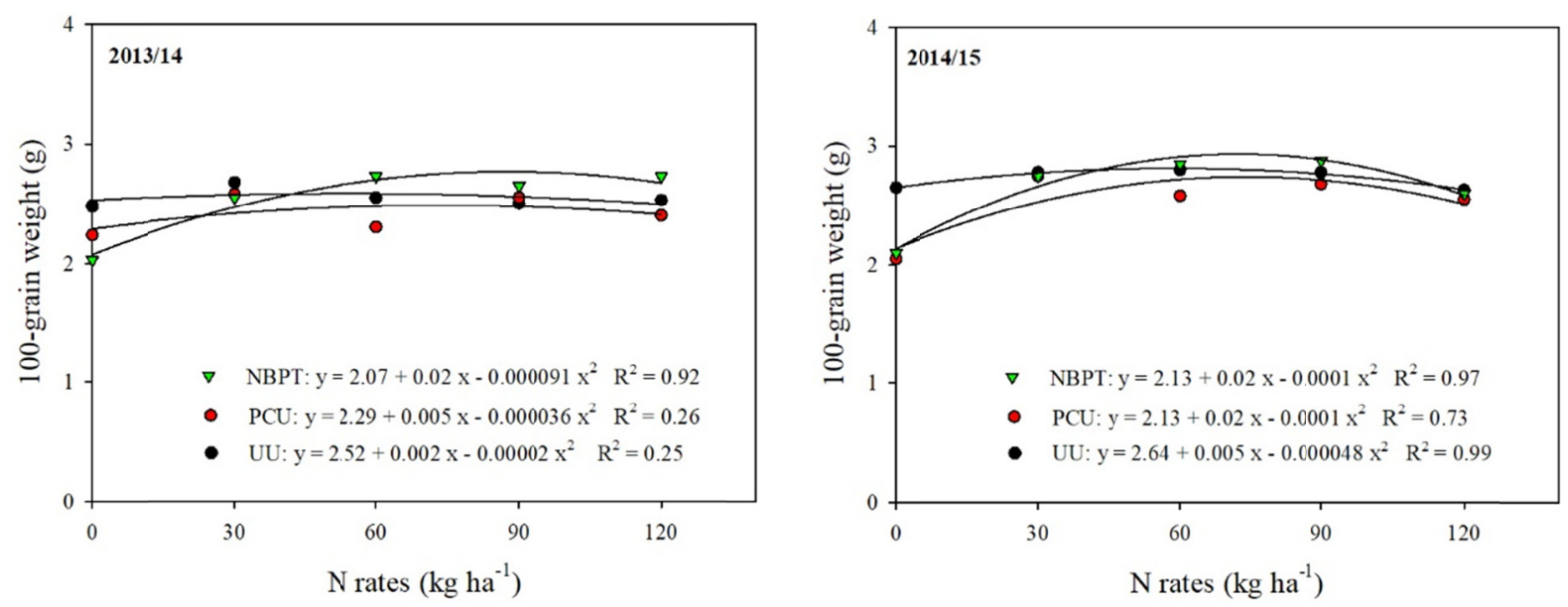

Figure 2. 100-grain weight of upland rice (cultivar BRS Esmeralda) as a function of $\mathrm{N}$ rates by untreated and uncoated urea (UU), polymer-coated urea (PCU) and urease inhibitor NBPT-treated urea (NBPT) during 2013/14 and 2014/15 growing seasons

Hence, we speculate that the grain weight of rice plants in our study was dependent on factors other than the $\mathrm{N}$ treatments, such as the water availability for the rice crop production. In a field experiment under drip irrigation and varying $\mathrm{N}$ rates, $\mathrm{Xu}$ et al. (2019) found increased rice grain yield due to an increase in the water and $\mathrm{N}$ use efficiency of rice with up to 50\% lower N application. Yang et al. (2017) also found inconsistent effects of 
slow-release fertilizers on field crop production in different rice growing seasons and attributed their findings to the influence of adverse meteorological conditions. In addition, other authors reported that the supply of $\mathrm{N}$ has little influence on the weight of 100 grains (Arf et al., 2003; Farinelli et al., 2004; Cazetta et al., 2008; Hernandes et al., 2010; Fidelis et al., 2012), which may also explain the inconsistency in our results.

The rice productivity also increased in a quadratic form with increasing the $\mathrm{N}$ rates in both seasons, varying from 2713 to $4764 \mathrm{~kg} \mathrm{ha}^{-1}$ in 2013/14, and from 2718 to $4640 \mathrm{~kg} \mathrm{ha}^{-1}$ in $2014 / 15 \mathrm{~kg} \mathrm{ha}^{-1}$ on average across the $\mathrm{N}$ rates regardless of the $\mathrm{N}$ sources (Figure 3). When the effect of $\mathrm{N}$ rates was analysed for each $\mathrm{N}$ source, maximum productivity was obtained with the application of $\mathrm{N}$ at a rate of $94 \mathrm{~kg} \mathrm{ha}^{-1}$ by UU, $111 \mathrm{~kg} \mathrm{ha}^{-1}$ by PCU, and $83 \mathrm{~kg}$ $\mathrm{ha}^{-1}$ by NBPT in the 2013/14 season, whereas $96 \mathrm{~kg} \mathrm{ha}^{-1}$ by UU, $79 \mathrm{~kg} \mathrm{ha}^{-1}$ by PCU, $76 \mathrm{~kg} \mathrm{ha}^{-1}$ by NBPT were needed to achieve the maximum rice productivity in 2014/15.

The rice productivity was higher under the application of NBPT-treated urea and polymer-coated urea in comparison with the application of untreated and uncoated urea in the 2013/14 season, but no difference among $\mathrm{N}$ sources was observed in the 2014/15 season (Table 3). Previous studies also reported higher positive effects of controlled-release urea over conventional urea on rice crop yield (Lyu et al., 2015; Zhang et al., 2018).
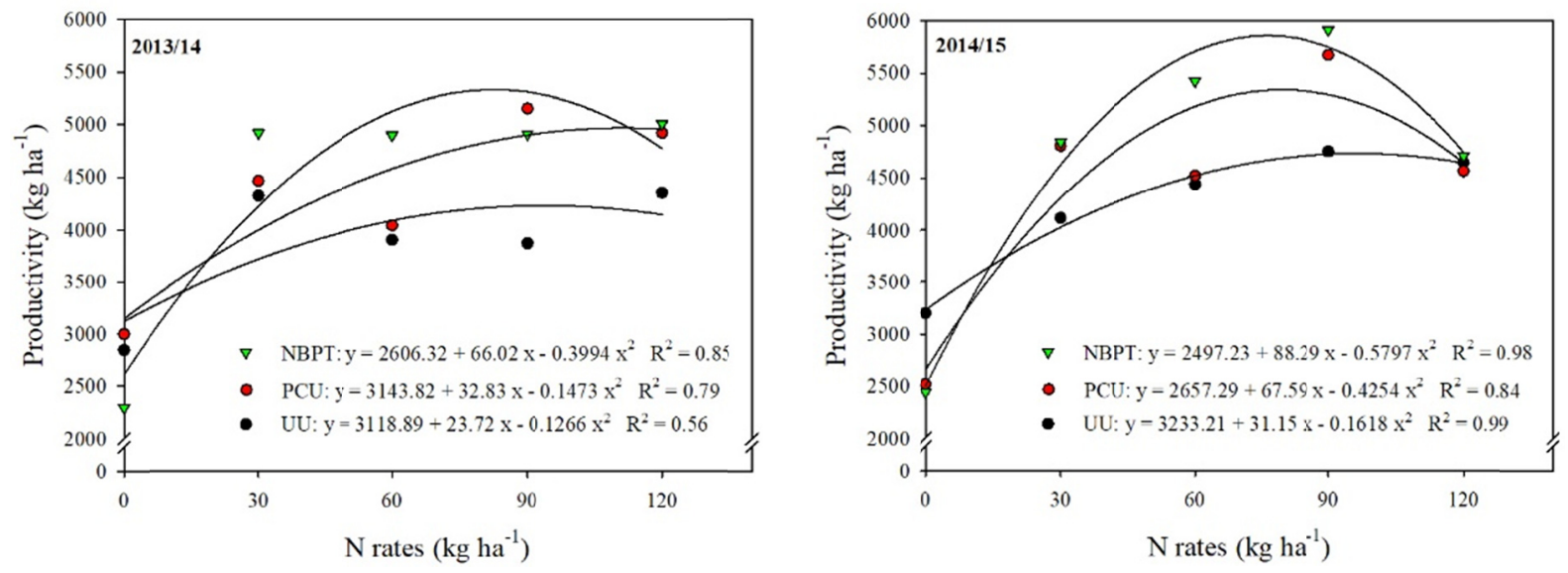

Figure 3. Productivity of upland rice (cultivar BRS Esmeralda) as a function of $\mathrm{N}$ rates by untreated and uncoated urea (UU), polymer-coated urea (PCU) and urease inhibitor NBPT-treated urea (NBPT) during 2013/14 and 2014/15 growing seasons

Better rice growth and production with NBPT and PCU treatments verified in our study may be attributed to the greater available $\mathrm{N}$ in the soil as a result of the higher $\mathrm{N}$ use efficiency of grain promoted by these sources. Recent reviews have been published on the mechanism of actions of enhanced efficiency fertilizers such as those used in this study (Singh, 2016; Cantarela et al., 2018). In summary, polymer-coated urea (PCU), which is produced by coating urea granules with function materials (i.e., sulphur, polyethylene, stach, and paraffin), can alleviate $\mathrm{N}$ loss mainly via physical obstacle caused by the functional materials coated on the surface of urea granules (Gao et al., 2015). On the other hand, the stabilized urea amended with urease inhibitor such as NBPT (N-(n-butyl)thiophosphoric triamide) can reduce $\mathrm{NH}_{3}$ emission and increase fertilizer $\mathrm{N}$ retention (Li et al., 2015). Therefore, PCU and NBPT as enhanced-efficiency $\mathrm{N}$ fertilizers have potential to increase the $\mathrm{N}$ availability in the soil and benefit the crop yield (Zhang et al., 2018).

The overall trend of the 2-yr experiments indicated that the difference in rice productivities verified only in 2013/14 was due to the effective N supply by the NBPT and PCU compared with the UU. However, given the environmental conditions that possibly affected the crop growth in the second year, no differences of $\mathrm{N}$ sources on rice productivities were verified in 2014/15.

Noteworthy, the absorption of $\mathrm{N}$ by rice plants is more pronounced in two stages throughout the cycle: at the beginning of tillering and floral primordium. In our study, the application of the basal $\left(10-30 \mathrm{~kg} \mathrm{ha}^{-1}\right)$ and cover $\left(20-70 \mathrm{~kg} \mathrm{ha}^{-1}\right)$ fertilizations at the time of sowing and tillering, respectively, as recommended by Embrapa (2009) may also have contributed to the absence of a higher significant difference between the $\mathrm{N}$ sources for rice productivity. 


\section{Conclusion}

The use of enhanced-efficiency $\mathrm{N}$ sources increased the productivity and plant height of upland rice crop when compared to conventional urea.

As compared to when it is untreated or polymner-coated, treating urea with NBPT resulted in increased 100-grain weight.

\section{Acknowledgements}

To the National Council for Scientific and Technological Development (CNPq) for the granting of a doctoral scholarship to the first author, and to the Foundation for Research Support of the State of Goias, Brazil (FAPEG) for the granting of a postdoctoral fellowship to the third author.

\section{References}

Arf, O., Rodrigues, R. A. F., Crusciol, C. A. C., Sá, M. E. D., \& Buzetti, S. (2003). Soil management and nitrogen fertilization for sprinkler-irrigated upland rice cultivars. Scientia Agricola, 60(2), 345-352. https://doi.org/10.1590/S0103-90162003000200020

Barbosa Filho, M. P., \& Yamada, T. (2002). Upland rice production in Brazil. Better Crops Int, 16, $43-47$.

Buresh, R. J., De Datta, S. K., Padilla, J. L., \& Samson, M. I. (1988). Field evaluation of two urease inhibitors with transplanted low-land rice. Agronomy Journal, 80, 763-768. https://doi.org/10.2134/agronj1988. $00021962008000050014 x$

Buresh, R. J., Ramesh Reddy, K., \& Van Kessel, C. (2008). Nitrogen transformations in submerged soils. Nitrogen in Agricultural Systems, 401-436. https://doi.org/10.2134/agronmonogr49.c11

Cantarella, H., Otto, R., Soares, J. R., \& de Brito Silva, A. G. (2018). Agronomic efficiency of NBPT as a urease inhibitor: A review. Journal of Advanced Research, 13, 19-27. https://doi.org/10.1016/j.jare.2018.05.008

Castro, A. P., Morais, O. P., Breseghello, F., Lobo, V. D. S., Guimarães, C. M., Bassinello, P. Z., ... Utumi, M. M. (2014). BRS Esmeralda: cultivar de arroz de terras altas com elevada produtividade e maior tolerância à seca. Embrapa Arroz e Feijão-Comunicado Técnico (INFOTECA-E).

Cazetta, D. A., Arf, O., Buzetti, S., Sá, M. E. D., \& Rodrigues, R. A. F. (2008). Desempenho do arroz de terras altas com a aplicação de doses de nitrogênio e em sucessão às culturas de cobertura do solo em sistema de plantio direto. Bragantia, 67(2), 471-479. https://doi.org/10.1590/S0006-87052008000200023

CGIAR. (2016). The global staple. Retrieved from http://ricepedia.org/rice-as-food/the-global-staplerice-consumers

Colombari Filho, J. M., de Resende, M. D. V., de Morais, O. P., de Castro, A. P., Guimaraes, E. P., Pereira, J. A., ... Breseghello, F. (2013). Upland rice breeding in Brazil: A simultaneous genotypic evaluation of stability, adaptability and grain yield. Euphytica, 192(1), 117-129. https://doi.org/10.1007/s10681-0130922-2

Dillon, K. A., Walker, T. W., Harrell, D. L., Krutz, L. J., Varco, J. J., Koger, C. H., \& Cox, M. S. (2012). Nitrogen sources and timing effects on nitrogen loss and uptake in delayed flood rice. Agronomy Journal, 104(2), 466-472. https://doi.org/10.2134/agronj2011.0336

Dobermann, A., \& Cassman, K. G. (2004). Environmental dimensions of fertilizer nitrogen: What can be done to increase nitrogen use eficiency and ensure global food security? In A. R. Mosier, J. K. Syers, \& J. R. Freney (Eds.), Agriculture and the Nitrogen Cycle: Assessing the Impacts of Fertilizer Use on Food Production and the Environment (pp. 261-278). SCOPE 65, Paris, France.

EMBRAPA (Empresa Brasileira de Pesquisa Agropecuária). (1997). Manual de métodos de análise de solo (2nd ed., p. 212). EMBRAPA-CNPS, Rio de Janeiro, RJ.

EMBRAPA (Empresa Brasileira de Pesquisa Agropecuária). (2009). Manual de análises químicas de solos, plantas e fertilizantes (2nd ed., p. 628). Informação Tecnológica, Brasília.

Fageria, N. K., \& Santos, A. B. (2018). Comparative Efficiency of Nitrogen Sources for Lowland Rice Production. Communications in Soil Science and Plant Analysis, 49(5), 515-525. https://doi.org/10.1080/ 00103624.2018.1424892

Fageria, N. K., Baligar, V. C., \& Jones, C. A. (2011). Growth and mineral nutrition of field crops (3rd ed., p. 3). CRC Press, BocaRaton, Florida. https://doi.org/10.1201/b10160 
Fageria, N. K., Moreira, A., \& Coelho, A. M. (2011). Yield and yield components of upland rice as influenced by nitrogen sources. Journal of Plant Nutrition, 34(3), 361-370. https://doi.org/10.1080/01904167.2011. 536878

FAO. (2019). Food Outlook-Biannual Report on Global Food Markets. Rome, Italy.

Farinelli, R., Penariol, F. G., Fornasieri Filho, D., \& Bordin, L. (2004). Características agronômicas de arroz de terras altas sob plantio direto e adubação nitrogenada e potássica. Revista Brasileira de Ciência do Solo, 28(3), 447-454. https://doi.org/10.1590/S0100-06832004000300006

Fidelis, R. R., Rodrigues, A. M., Silva, G. F., Barros, H. B., Pinto, L. C., \& Aguiar, R. W. S. (2012). Eficiência do uso de nitrogênio em genótipos de arroz de terras altas. Pesquisa Agropecuária Tropical, 42(1), $124-128$. https://doi.org/10.1590/S1983-40632012000100018

Francis, D. D., Vigil, M. F., \& Mosier, A. R. (2008). Gaseous losses of nitrogen other than through denitrification. Nitrogen in Agricultural Systems, 255-279. https://doi.org/10.2134/agronmonogr49.c8

Gao, X., Li, C. L., Zhang, M., Wang, R., \& Chen, B. C. (2015). Controlled release urea improved the nitrogen use efficiency: Yield and quality of potato (Solanum tuberosum L.) on silt loamy soil. Field Crops Research, 181, 60-68. https://doi.org/10.1016/j.fcr.2015.07.009

Guo, L. W., Ning, T. Y., Nie, L. P., Li, Z. J., \& Lal, R. (2016). Interaction of deep placed controlled-release urea and water retention agent on nitrogen and water use and maize yield. European Journal of Agrononomy, 75, 118-129. https://doi.org/10.1016/j.eja.2016.01.010

Heinemann, A. B., Stone, L. F., \& Fageria, N. K. (2011). Transpiration rate response to water deficit during vegetative and reproductive phases of upland rice cultivars. Scientia Agricola, 68(1), 24-30. https://doi.org/10.1590/S0103-90162011000100004

Hernandes, A., Buzetti, S., Andreotti, M., Arf, O., \& Sá, M. E. D. (2010). Doses, fontes e épocas de aplicação de nitrogênio em cultivares de arroz. Ciência e Agrotecnologia, 34(2), 307-312. https://doi.org/10.1590/ S1413-70542010000200006

Ladha, J. K., Pathak, H., Krupnik, T. J., Six, J., \& van Kessel, C. (2005). Efficiency of fertilizer nitrogen in cereal production: Retrospects and prospects. Advances in agronomy, 87, 85-156. https://doi.org/10.1016/ S0065-2113(05)87003-8

Li, Q., Yang, A., Wang, Z., Roelcke, M., Chen, X., Zhang, F., ... Liu, X. (2015). Effect of a new urease inhibitor on ammonia volatilization and nitrogen utilization in wheat in north and northwest China. Field Crops Research, 175, 96-105. https://doi.org/10.1016/j.fcr.2015.02.005

Linquist, B. A., Liu, L., van Kessel, C., \& van Groenigen, K. J. (2013). Enhanced efficiency nitrogen fertilizers for rice systems: Meta-analysis of yield and nitrogen uptake. Field Crops Research, 154, $246-254$. https://doi.org/10.1016/j.fcr.2013.08.014

Lyu, X., Yang, Y., Li, Y., Fan, X., Wan, Y., Geng, Y., \& Zhang, M. (2015). Polymer-coated tablet urea improved rice yield and nitrogen use efficiency. Agronomy Journal, 107(5), 1837-1844. https://doi.org/10.2134/ agronj14.0629

Norman, R. J., Wilson, C. E., Slaton, N. A., Griggs, B. R., Bushong, J. T., \& Gbur, E. E. (2009). Nitrogen fertilizer sources and timing before flooding dry-seeded, delayed-flood rice. Soil Science Society of America Journal, 73(6), 2184-2190. https://doi.org/10.2136/sssaj2008.0309

Pang, G. B. \& Peng, S. Z. (2010) Research advances of nitrogen fertilizer application technologies in Chinese rice field. Soil, 42, 329-335.

Patil, M. D., Das, B. S., Barak, E., Bhadoria, P. B., \& Polak, A. (2010). Performance of polymer-coated urea in transplanted rice: Effect of mixing ratio and water input on nitrogen use efficiency. Paddy and Water Environment, 8(2), 189-198. https://doi.org/10.1007/s10333-010-0197-3

Rogers, C. W., Norman, R. C., Brye, K. R., Slaton, N. A., \& Smartt, A. D. (2015). Comparison of urease inhibitors for use in rice production on a silt-loam soil. Crop Forage Turfgrass Manage, 1(1), 1-6. https://doi.org/10.2134/cftm2014.0062

Santos, H. D., Jacomine, P. K. T., Anjos, L. D., Oliveira, V. D., Lumbreras, J. F., Coelho, M. R., ... Oliveira, J. D. (2013). Sistema brasileiro de classificação de solos (p. 353). Brasília: Embrapa Solos. 
Sinclair, T. R., \& Rufty, T. W. (2012). Nitrogen and water resources commonly limit crop yield increases, not necessarily plant genetics. Global Food Security, 1(2), 94-98. https://doi.org/10.1016/j.gfs.2012.07.001

Singh, B. (2016). Agronomic benefits of neem coated urea-a review. International fertilizer association review papers. Paris: International Fertilizer Association.

Singh, V. B., \& Singh, V. K. (2017). Fertilizer management in rice. Rice production worldwide (pp. 217-253). Springer, Cham. https://doi.org/10.1007/978-3-319-47516-5_10

Soil Survey Staff. (2003). Keys to soil taxonomy. Department of Agriculture: Natural Resources Conservation Service.

Tilman, D., Cassman, K. G., Matson, P. A., Naylor, R. L., \& Polasky, S. (2002). Agricultural sustainability and intensive production practices. Nature, 418, 671-677. https://doi.org/10.1038/nature01014

Witt, C., Dobermann, A., Abdulrachman, S., Gines, H. C., Guanghuo, W., Nagarajan, R., ... Olk, D. C. (1999). Internal nutrient eficiencies in irrigated lowland rice of tropical and subtropical Asia. Field Crops Res., 63, 113-13. https://doi.org/10.1016/S0378-4290(99)00031-3

Xu, G. W., Lu, D. K., Wang, H. Z., \& Li, Y. J. (2018). Morphological and physiological traits of rice roots and their relationships to yield and nitrogen utilization as influenced by irrigation regime and nitrogen rate. Agricultural Water Management, 203, 385-394. https://doi.org/10.1016/j.agwat.2018.02.033

Xu, G. W., Song, K. J., Lu, D. K., Wang, H. Z., \& Chen, M. C. (2019). Influence of water management and nitrogen application on rice root and shoot traits. Agronomy Journal, 111(5), 2232-2244. https://doi.org/ 10.2134/agronj2019.02.0096

Yang, Y., Liu, B., Yu, L., Zhou, Z., Ni, X., Tao, L., \& Wu, Y. (2018). Nitrogen loss and rice profits with matrix-based slow-release urea. Nutrient Cycling in Agroecosystems, 110, 213-225. https://doi.org/ 10.1007/s10705-017-9892-4

Yang, Y., Ni, X., Zhou, Z., Yu, L., Liu, B., Yang, Y., \& Wu, Y. (2017). Performance of matrix-based slow-release urea in reducing nitrogen loss and improving maize yields and profits. Field Crops Research, 212, 73-81. https://doi.org/10.1016/j.fcr.2017.07.005

Ye, Y. S., Liang, X. Q., Chen, Y. X., Liu, J., Gu, J. T., Guo, R., \& Li, L. (2013). Alternate wet and dry irrigation and controlled-release nitrogen fertilizer in late-season rice. Effects on dry matter accumulation, yield, water and nitrogen use. Field Crops Research, 144, 212-224. https://doi.org/10.1016/j.fcr.2012.12.003

Zhang, S., Shen, T., Yang, Y., Li, Y. C., Wan, Y., Zhang, M., ... Allen, S. C. (2018). Controlled-release urea reduced nitrogen leaching and improved nitrogen use efficiency and yield of direct-seeded rice. Journal of Environmental Management, 220, 191-197. https://doi.org/10.1016/j.jenvman.2018.05.010

\section{Copyrights}

Copyright for this article is retained by the author(s), with first publication rights granted to the journal.

This is an open-access article distributed under the terms and conditions of the Creative Commons Attribution license (http://creativecommons.org/licenses/by/4.0/). 